\title{
WHAT THE HISTORIAN ASKS OF THE LIBRARIAN
}

\author{
BY JULIAN P. BOYD
}

Julian P. BoyD, after graduating from Duke University, taught history briefly at the University of Pennsylvania and then served successively as Editor of the Wyoming Historical and Geological Society, Director of the New York State Historical Association, and Librarian of the Historical Society of Pennsylvania. In 1940 he became Librarian of Princeton University and occupied that position during the planning and preparation of the building of its new Firestone Library. In $195^{2}$ he became Professor of History and is currently editor of the imposing project of the successive volumes of The Papers of Thomas Jefferson.

DISTINGUISHED AMERICAN HISTORIAN remarked
a few years ago that if he really wanted to know what
Greek civilization was like in the age of Homer he would ask for the Athenian equivalent of the Sears Roebuck Catalogue. The remark was not facetious. It was uttered in a discussion of the most serious problem confronting a library-that is, the problem of selecting from the world's store of recorded knowledge those particular items that will meet the needs of the library's fluid and unpredictable constituency. Indeed, in that rather informed group of scholars and librarians the Sears Roebuck Catalogue was taken for granted as a source of considerable importance for cultural historians. When the discussion probed deeper it arrived inevitably at the conclusion that there is literally nothing on which the mark of human hands has been left that cannot be of some use to the historian in the pursuit of his ancient art of observing, recording, and interpreting the story of human kind. Even those scribblings that the modern undergraduate is under such compulsion to put in the margins of library books may tell the future historian somethingnot much, perhaps, but something. Who knows, some undergraduate at Rutgers today may bring to the historian five centuries hence the same delight that we feel on encountering the Gaelic glosses to a Latin text that a medieval Irish monk placed in the margin of his vellum sheets, such as: "St. Patrick of Armagh, deliver me from writing"; or "O that a glass of good old wine were by my side"; 
or "Well, this vellum is hairy." These to the medieval historian are useful gleanings, even if they convey only the fact that the medieval monk in his scriptorium, like the modern student in the reading room of the library, did not always have his mind on his business.

There is, unhappily, no such thing as an Athenian Sears Roebuck Catalogue of the time of Homer, or even an approximate equivalent. But, as every librarian knows, the fact that a book is nonexistent does not mean that even such humane and reasonable users as historians will not ask that it be produced. In the realm of the extant record, however, the historian's demands upon the librarian are quite simple. All he wants is the precise book he needs at the very moment the need arises. Now, according to some very intelligent estimates, made not by historians but by librarians, there are some fifteen to twenty million titles of works of research value that have accumulated in all lands, all languages, and all libraries of the world since the beginning of printing. Only a fraction of these is to be found within the limits of continental United States, and when this fraction is further fragmented among the hundreds of research libraries, it is easy to see that even the largest and best endowed university library is but a fraction of what the historian needs today or may need tomorrow morning. But let us note that these fifteen or twenty million titles are research works: They do not include fiction, periodicals, government documents, maps, and a great multitude of other products of the printing press. They embrace none of the great flood of materials released by the United Nations and by hundreds of governmental and private agencies devoted to the preservation of peace, nor the millions of pieces of scientific data, intelligence reports, investigative findings, and memoranda related to preparation for war. They include none of the organizational literature, in the fields of business, education, religion, or even the library world. To take a single example of a single sub-category, they omit such a valuable source for the historian as the house organ of the New York Times, one of the best and most informative, but only one of thousands of house organs that the historian must confront. Yet all of this vast record comes within his inclusive domain, and it must be recorded that the librarian has joined the historian 
in staking out that all-embracing claim. I myself, as a former librarian, plead guilty to the unavoidable complicity.

If I have given you the impression that the fifteen to twenty million research titles, plus these peripheral items, constitute the whole of the sources needed by the historian, then I have grossly misled you. All of that, together with a vast lot of additional categories that I have not time to mention, make up only a fraction of what the historian needs or thinks he needs. The sources that I described are only those relating to Johannes Gutenberg's epochal invention of a feasible means of printing from moveable types. This occurred only a brief five hundred years ago, and for thousands of years before that man had been busy putting an increasing number of marks on paper and other materials without the aid of printing. All of these great mountain ranges of sources lie within the historian's province, and if he is not monarch of all he surveys, at least he lays claim to all. This larger fragment of the human record, by which countless individuals of the species projected their thoughts great and small across continents and centuries, includes the cuneiform tablets, cones, and cylinders of the Assyrian empire, on which scribes pressed their styluses when the clay was wet twenty-five centuries ago, telling us what they had to say in their contracts, wills, deeds, and letters. The shoulder blade of a camel, basalt tablets, massive sheets of copper and lead, papyrus scrolls, the bark of trees, animal skins, textiles, stones - all of these materials and many others have been used as the stuff on which "books" needed and used by the historian have been written. In the great library of Byzantium before it was destroyed, there was even one record, if we may believe the usually reliable Justus Lipsius, that any historian would have been happy to see. "Among the books," he said, "was the gut of a great dragon, one hundred and twenty feet long, on which was written in letters of gold the whole of the Iliad and the Odyssey."

For several centuries the Islamic world kept the lamp of learning bright by preserving much of the wisdom of Greece and Rome for future historians, and for centuries afterward the scribes of western Europe in their monasteries added volume after volume to the growing mountain of sources, some of it inspiring to contemplate, some of it a dreary waste. Yet even the "corrupt versions of useless texts in 
illegible scripts" had their value for the historian, if only to prove that manuscript books in ages of both religious and cultural degeneration "were sometimes still transcribed ... through a mere momentum of habit and tradition," as some unfortunately are today.

But even the great sea of written words produced by the rebirth of humane learning, by the Reformation, and by the expansion of business enterprise attendant upon the growth of the national state are small puddles compared with the vast pile of records produced in the industrial and government community of a single great modern power. If it is true that all of the energy used by mankind from the birth of Christ to our day is but an infinitesimal part of the energy available in this nuclear age, it is also true that the amount of source records produced by man from the first drawings on caves to this century are a fraction of those generated within a year in the scientific, industrial, and governmental community of the United States alone.

What bureaucracy has failed to do in the way of augmenting records, technology has supplied. The ancient Chinese who carved the Oriental classics on stone were slow producers even with cheap and plentiful labor; but one man or woman with a camera can today produce millions of new documents for the historian, and thousands of people do. The camera can, of course, prevaricate, distort with bias, and perform all of the other subjective functions of which the historian himself is capable. But it has within the past hundred years produced a new and expanding kind of record. "With the exception of a few cameras clicking in the wilderness," says one historian, "there was for a long time no perception of the possibilities of photographic documentation of living history. . . . Samuel Pepys' description of London life during the Restoration is among the most vivid and intimate to which historians have access; yet that description would undoubtedly be much more vivid and real if Pepys had carried with him a minature camera with F.2 lens and sychronized flashbulb equipment." Historians are quick to learn, and so they now have to analyze and use pictures showing St. Anthony's Soup Kitchen in Hoboken in 1940; the interior of a General Store in Moundville, Alabama, in 1936; the pitiable spectacle of the Negro mother of a sharecropper family in Louisiana teaching her children the alphabet; the lower wharf of Yorktown, Virginia, in I 862, piled high with 
mortars, rifled artillery, cannon balls, and other matériel; the very moving Madonna-like picture of a young Italian immigrant and her child at Ellis Island in I905; and billions of other graphic extensions of the written word that have added enormously to the sources that a historian must cope with.

The new technology was busily multiplying sources on its own initiative without needing any help from anyone, when the introduction of a new dimension in human records opened up vast possibilities that intoxicated historians so much that some of them even plunged in to speed up the process. The phonograph and the tape recorder held no alarming prospects as long as they were employed for the transmittal of music or the preservation of a speech by Woodrow Wilson or the reading of poems. But the human race has never been distinguished for its tendency to let well enough alone, and so the historian, reflecting his own natural longing to hear Lincoln speak the Gettysburg Address or Webster reply to Hayne, set about doing his duty by the historian of the future. He began recording what he called oral history. It is no wonder that a new venture in this area is called Sound Unlimited.

Now there is no dependable evidence on which we can estimate the rate of speed at which the medieval monks copied or wrote their beautifully illuminated manuscripts. We know that, according to their own complaints, they employed three fingers to hold the pen, as well as every other muscle in the body; that their eyes were ruined, their stomachs twisted, and their backs wracked and tormented. In brief, they wrote slowly and painfully, producing only a few hundred pages in a lifetime of work. Consider, by way of contrast, the verbal output possible for a retired politician who has nothing to do but try to justify to posterity the discrepancy between the millions of words he uttered on the hustings and the few recorded deeds of his incumbency. In the quiet of his comfortable study, faced by a microphone, an interlocutor, and the record of his past, he can easily reel off two or three million vocalized words, and some have actually done so. He may not outstrip the medieval monk in the beauty of the final result, but quantitatively he has him beat hands down.

The historian not only assumes everything for his province, but, as I have tried to suggest by the examples I have cited, his needs, his approaches to history, and his methods are constantly changing. Thus 
we must recognize that the demands made by the historian upon the librarian are limitless and unforeseeable. The historian and the librarian are therefore civilization's most incurable romanticists, partners in idealism on a Homeric scale. Many others dare to accomplish the impossible, but the uniqueness of their endeavor lies in the fact that the nearer they approach success the more remote the goal becomes.

There are some hopeful signs and some built-in safety devices. No one can hope to read or even to see more than a minute fraction of the fifteen million titles that I mentioned earlier. But there are thousands of reflective minds at work on this great mountain, burrowing here, there, and everywhere. It is very unlikely that any unsung Milton lies neglected beneath the surface. Libraries, teaching, and the whole scholarly process are guarantees that the purest ore is always brought to the surface. Moreover, technology has now made it possible to create miraculous machines that can store, memorize, and service even vaster accumulations of records than any library possesses. These, if we are wise, can be used for the accommodation of those arid deserts of records threatening to overwhelm us, freeing the library to devote its energy, as in the beginning, to humane learning. They can be used for these purposes, that is, if the librarians can persuade the historians by guile or by threat to make use of the new techniques. For, while historians have shown great eagerness in changing their emphasis from one kind of source to another, there is one respect in which they do not change. They have become so accustomed to the book that anything not in the rectangular form of a codex fills them with alarm and dread, and they complain that the new techniques ruin the eyes, bring on headaches, and have other harmful physiological effects, which, they imply, the book does not. Perhaps in this situation the precedent for the librarian exists in the signature of a 9th century manuscript, which the scribe ended with these words: "Jacob wrote this." Underneath, in the hand of the monk's superior, was this further comment: "A certain portion of this book is not of [Jacob's] own free will but under compulsion, bound by fetters, just as a runaway and fugitive has to be bound." Such a fate surely would not be too harsh for the profession that invented oral history. 
Yet, heroic idealists though they are, historians and librarians are the most indispensable pillars of civilization. Destroy them, destroy the functions they perform, and you destroy civilization itself. There are substitutes for such material resources as oil and coal. There are no substitutes for these laborers in the vineyard who preserve and use and place at the disposal of society the long written record of the human race, and if they and the record are once destroyed, there is no alternative but to begin again. Indeed, in that event humanity would begin under handicaps that it did not experience in its first dawn. When the task of the historian and the librarian was in its pristine simplicity, human beings were capable of storing in memory and of reciting to the tribal councils such epics as the Iliad and the Odyssey. But our long reliance on the greatest of all technological advances, that of recording words and ideas, has all but atrophied the human memory. No living person or groups of persons could today replace from memory, once the record were obliterated, Beowulf or Shakespeare or Homer or the Bible or any of the great encyclopedias. Our memories are enslaved to the record, as civilization is, but it is a slavery in which our greatest potentialities lie.

A measure of civilization is the value it places upon this human record and upon its interpreters and custodians. In seventh century Ireland the penalty for killing a scribe was as great as that for killing a bishop, and in the next century at Tours, Alcuin took the monks away from field labor, telling them that the pursuit of learning and the creative act of writing were nobler pursuits. These tiny straws tell us something about the scale of values of the society that produced them. So, too, a society that pays its plumbers and undertakers more than it pays its teachers and librarians tells us something about its estimate of relative values. "Taxes," said Mr. Justice Holmes, "are what we pay for civilized society." The citizen of New Jersey, as he contemplates this building and the prospect of that unending miracle by which teachers introduce young minds to the glories and some of the follies of the human record here displayed may well feel a glow of pride. His taxes have helped--but have only helped-pay for one of the most valuable of all institutions. For the greatest contribution to it has been made by teachers, librarians, and users of libraries. 